\title{
Genetic diversity in Indian common bean (Phaseolus vulgaris L.) using random amplified polymorphic DNA markers
}

\author{
Vipin Kumar ${ }^{1}$, Shailendra Sharma ${ }^{1}$, Amit Kumar Sharma ${ }^{1}$, Mukesh Kumar ${ }^{1}$, Shiveta Sharma ${ }^{2}$, Sunil Malik ${ }^{1}$, \\ K.P. Singh ${ }^{2}$, R.S. Sanger ${ }^{1}$ and K.V. Bhat ${ }^{3}$ \\ ${ }^{1}$ Sardar Vallabh Bhai Patel University of Agriculture \& Technology, Modipuram, Meerut - 250 110, U.P., India \\ ${ }^{2}$ Department of Genetics \& Plant Breeding, Institute of Agricultural Sciences, Banaras Hindu University, \\ Varanasi - 221 005, U.P., India \\ ${ }^{2}$ Department of Horticulture, A.S. College Lakhaoti. Bulandshahar, U.P., India \\ ${ }^{3}$ NRC on DNA Fingerprinting, National Bureau of Plant Genetic Bureau of Plant Genetic Resources \\ (NBPGR), Pusa Campus, New Delhi - 110 012, India
}

\begin{abstract}
Genetic diversity of twenty-six common bean (Phaseolus vulgaris L.) accessions of diverse geographical origin was studied using Random Amplified Polymorphic DNA (RAPD) markers. Fifteen out of forty four primers screened showed polymorphism across present set of genotypes. A total of 124 amplicons were scored using these 15 primers. Ninety five percent of the amplified products showed polymorphism, indicating fair amount of variation at the DNA level among these accessions. Cluster analysis delineated the genotypes in to four groups. [Physiol. Mol. Biol. Plants 2008; 14(4) : 383-387] E-mail : Vipinch1@yahoo.co.in
\end{abstract}

Key words : Genetic diversity, Common bean, RAPD, UPGMA

\section{INTRODUCTION}

Common bean (Phaseolus vulgaris L.; $2 \mathrm{n}=2 \mathrm{x}=22$ ) is a predominantly self-pollinated crop originated mainly in Latin America. From Latin America, it spread to other parts of world and now it is widely cultivated in the tropics and subtropics as well as in temperate regions of the world (Gepts and Bliss 1988; Zeven 1997, 1999).

In India, common bean is known by the names like 'Rajmash' and 'Frash bean (green bean)' and grows in certain parts of the country. Indian farmers are also growing it due to its good market price and it is mainly consumed as grain legume. Common bean production in India is 4,340 million tones as compared 18,943 million tones in the world. (Anonymous, 2003). In due course of time many common bean varieties have been released in India by different research institutes. A great diversity for agro-morphological traits like, seed size and colour also exists in Phaseolus germplasm of northwestern Himalayan region comprising the parts of Himachal

Correspondence and Reprint requests : Vipin Kumar
Pradesh and Jammu and Kashmir State of India. But still there is need to select genetically diverse.

Parental lines to obtain superior recombinants. Conventionally, the identification of genetically distinct genotypes is accomplished by using morphological characteristics, which is later supplemented with molecular markers for reliable results. In the present study an effort was made to assess the genetic diversity among released varieties from India and abroad using RAPD markers. Random amplified polymorphic DNA (RAPDs) markers have been utilized successfully by many workers for genetic diversity analysis in common bean (Beebe et al. 2000; Metais et al., 2002; Sharma et al. 2006). These markers are selected because they are technically simple, rapid, comparatively cheap, does not require the use of radio activity and very small quantity of DNA is required for RAPD analysis.

\section{MATERIALS AND METHODS}

\section{Plant materials}

A total of 26 accessions including high yielding released 
Table 1. Common bean accessions subjected to RAPD analysis to determine genetic diversity

\begin{tabular}{|c|c|c|c|c|}
\hline Sl.No. & Accessions & Name of variety & Source & State \\
\hline 1. & $\mathrm{IC} 73559^{\star 1}$ & VL RAJMA 63 & VPKAS, Almora & Uttranchal \\
\hline 2. & IC $393852^{\star 1}$ & VARUN (ACPR-94040) & Regional fruit Station Pune & Maharastra \\
\hline 3 & IC $296363 \star 1$ & IC296363 & IIPR, Kanpur & Uttar Pradesh \\
\hline 4. & 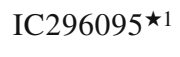 & K-31 (F-BEAN) & MPKVV, Rahuri & Maharastra \\
\hline 5. & IC $393851^{\star 1}$ & MUTHA (HPR-35) & Regional fruit Station Pune & Maharastra \\
\hline 6. & IC $326537^{\star 1}$ & KAILASH (SRC-74) & $\begin{array}{l}\text { Ch. Swaran Kumar Krishi } \\
\text { Vishwavidyalaya }\end{array}$ & $\mathrm{HP}$ \\
\hline 7. & IC296096 & VARUN & MPKVV, Rahuri & Maharastra \\
\hline 8. & IC295928 & OOTY (FB-2) & HRS, Vijaynagaramooty & Tamilnadu \\
\hline 9. & IC296097 ^1 & BEAN-1 (GUJRAT BEAN) & GAU, VRC, Anand & Gujarat \\
\hline 10. & IC $296098^{\star 1}$ & IIPR-96-4 (AMBER) & IIPR, Kanpur & Uttar Pradesh \\
\hline 11. & IC $296331 \star 1$ & IIPR-96-3 (RUDRA) & IIPR, Kanpur & Uttar Pradesh \\
\hline 12. & IC393734 $4^{\star 1}$ & IIHR- 909 (ARKA SUVIDHA) & IIHR, Bangalore & Karnataka \\
\hline 13. & IC75267^1 & ARKA KOMAL & IIHR, Bangalore & Karnataka \\
\hline 14. & IC73041 $1^{\star 1}$ & HPR-12 (JWALA) & $\begin{array}{l}\text { Ch. Swaran Kumar Krishi } \\
\text { Vishwavidyalaya }\end{array}$ & $\mathrm{HP}$ \\
\hline 15 . & IC73040^1 & HIM-1 & $\begin{array}{l}\text { Ch. Swaran Kumar Krishi } \\
\text { Vishwavidyalaya }\end{array}$ & $\mathrm{HP}$ \\
\hline 16. & IC73039 $9^{\star 1}$ & HPR-62 (HANS) & $\begin{array}{l}\text { Ch. Swaran Kumar Krishi } \\
\text { Vishwavidyalaya }\end{array}$ & $\mathrm{HP}$ \\
\hline 17. & 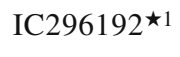 & OOTY-1 & TN. Agr. Uni. & Tamilnadu \\
\hline 18. & $\mathrm{IC} 121427^{\star 1}$ & IC121427 & IARI, Katrain, H.P. & HP \\
\hline 19. & $\mathrm{IC} 118935^{\star 1}$ & HUR-137 (MALVIYA RAJMA) & BHU, Varanasi & Uttar Pradesh \\
\hline 20. & IC $118984^{\star 1}$ & HUR-15 (MALVIYA RAJMA 15) & BHU, Varanasi & Uttar Pradesh \\
\hline 21. & IC118933^1 & UDAY (PDF -14) & DPR, Kanpur & Uttar Pradesh \\
\hline 22. & $\mathrm{IC} 79115^{\star 1}$ & PANT ANUTTAR PRADESHAMA & Agr. Uni. Pant Nagar & Uttranchal \\
\hline 23. & IC76299^1 & CONTANDER & IARI, Katrain, H.P. & HP \\
\hline 24. & IC76298 $\star 1$ & PUSA PARVATI & IARI, Katrain, H.P. & HP \\
\hline 25. & $\mathrm{IC} 76281^{\star 1}$ & KENTUKEY WONDER & IARI, Katrain, H.P. & HP \\
\hline 26. & IC $384680^{\star 1}$ & SHALIMAR RAJMA (LAL RAJMA) & $\begin{array}{l}\text { Share Kashmir Uni. of } \\
\text { Agr. \& Sciences }\end{array}$ & $\mathrm{J} \& \mathrm{~K}$ \\
\hline
\end{tabular}


Table 2. List of primers along with their sequences and amplification details

\begin{tabular}{|c|c|c|c|c|c|}
\hline Primer & Sequence $\left(5^{\prime}-3^{\prime}\right)$ & $\begin{array}{c}\text { No. of } \\
\text { amplified } \\
\text { fragments }\end{array}$ & $\begin{array}{c}\text { No. of } \\
\text { polymorphic } \\
\text { fragments }\end{array}$ & $\begin{array}{c}\text { Polymorphism } \\
(\%)\end{array}$ & $\begin{array}{l}\text { Mol. Wt range } \\
(\mathbf{k b})\end{array}$ \\
\hline OPA-08 & GTGACGTAGG & 8 & 8 & 100 & $0.2-2.5$ \\
\hline OPA-11 & CAATCGCCGT & 7 & 7 & 100 & $0.2-2.0$ \\
\hline OPA-12 & TCGGCGATAG & 4 & 4 & 100 & $0.3-1.5$ \\
\hline OPA-13 & CAGCACCCAC & 5 & 4 & 80 & $0.25-1.7$ \\
\hline OPA-14 & TCTGTGCTGG & 10 & 10 & 100 & $0.25-2.5$ \\
\hline OPA-15 & TTCCGAACCC & 10 & 10 & 100 & $0.3-1.9$ \\
\hline OPA-16 & AGCCAGCGAA & 4 & 4 & 100 & $0.6-1.5$ \\
\hline OPA-17 & GACCGCTTGT & 6 & 6 & 100 & $0.2-2.5$ \\
\hline OPA-18 & AGGTGACCGT & 17 & 16 & 94 & $0.2-2.0$ \\
\hline OPB-01 & GTTTCGCTCC & 11 & 10 & 90 & $0.3-2.0$ \\
\hline OPB-03 & САТСССССТG & 6 & 5 & 83 & $0.3-2.0$ \\
\hline OPB-04 & GGACTGGAGT & 8 & 8 & 100 & $0.3-2.0$ \\
\hline OPB-05 & TGCGCCCTTC & 9 & 9 & 100 & $0.5-2.0$ \\
\hline OPB-07 & GGTGACGCAG & 12 & 12 & 100 & $0.25-2.5$ \\
\hline OPB-08 & GTCCACACGG & 7 & 6 & 85 & $0.3-2.5$ \\
\hline
\end{tabular}

varieties of common bean were used in the present study (Table 1)

\section{DNA isolation}

DNA was extracted from one-month-old young furled leaves following modified CTAB method of Saghai Maroof et al. (1984). DNA quality and quantity was checked on agarose gel with $\lambda \backslash H$ ind III DNA marker.

\section{RAPD analysis}

PCR reactions were performed in $25 \mu \mathrm{l}$ reaction mix containing $10 \mathrm{mM}$ Tris- $\mathrm{HCl}$ (pH 8.3), $50 \mathrm{mM} \mathrm{NaCl}, 2.5$ $\mathrm{mM} \mathrm{MgCl}_{2}, 200 \mu \mathrm{M}$ each of dATP, dTTP, dCTP and dGTP, $0.75 \mathrm{U}$ of Ampli Taq DNA polymerase (all reagents from Perkin Elmer Cetus), $0.6 \mu \mathrm{M}$ of 10-mer random primer (Operon Technologies, Alameda, CA) (Table 2) and $20 \mathrm{ng}$ of template DNA. Amplifications were performed in a 96-well thermocycler (Gene Amp 9600, Perkin Elmer Corporation, USA). PCR cycling conditions were as follows: $1 \mathrm{~min}$ denaturation at $93{ }^{\circ} \mathrm{C}, 1 \mathrm{~min}$ primer annealing at $35^{\circ} \mathrm{C}$ and $1 \mathrm{~min}$ primer extension at

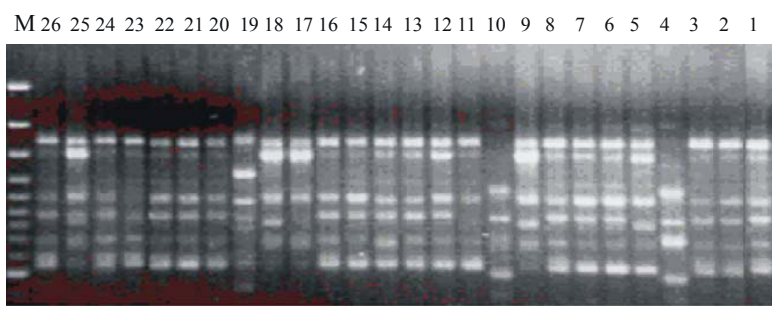

$\mathbf{a}$

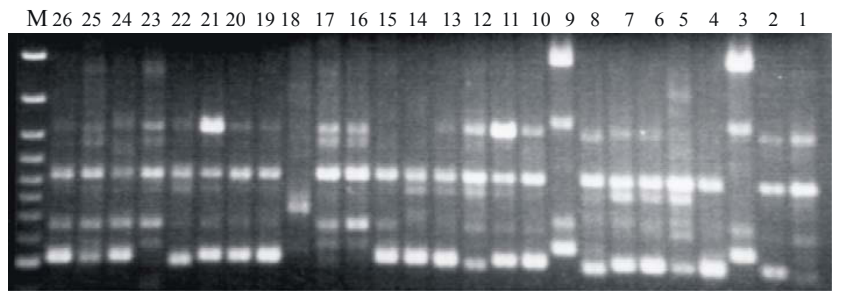

b

Fig. 1. PCR amplification patterns showing polymorphism detected by an RAPD primer OPA-15 (a) and OPB-4 (b) in different cultivars of common bean. $\mathrm{M}=100 \mathrm{bp}$ ladder. Numbers 1-26 represents different varieties as given in the Table 1. 


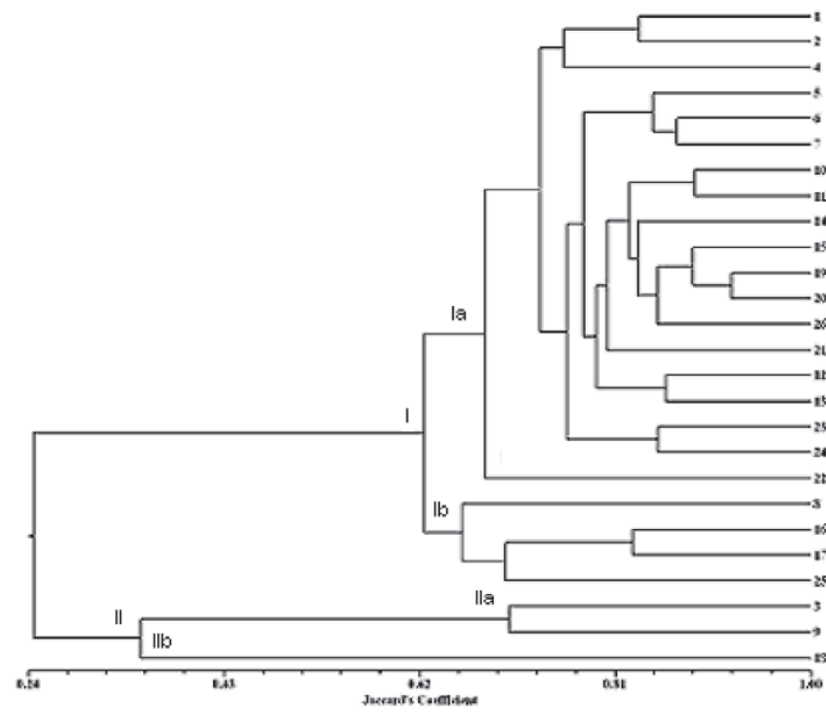

Fig. 2. Dendrogram showing clustering pattern of 26 common bean released cultivars based on genetic similarity values obtained from the RAPD data. Numbers 1-26 represents different varieties as given in Table 1 .

$72{ }^{\circ} \mathrm{C}$ for 40 cycles followed by a further extension at $72{ }^{\circ} \mathrm{C}$ for $8 \mathrm{~min}$. Amplified products were mixed with loading buffer containing bromophenol blue, separated through gel electrophoresis on $1.4 \%$ agarose (Bio-Rad, USA) gels in $1 \mathrm{x}$ TAE buffer, stained with ethidium bromide and PCR products visualized on a UV transilluminator. The intensity of fluorescence of different ethidum bromide stained PCR products varied within and among the cultivars studied. For purposes of data analysis only amplicons that were reproduced over two amplifications were included.

\section{Analysis of Data}

Gels were scored in binary format with the presence of band scored as one and its absence scored as zero. The binary data were used to compute pair-wise similarity coefficients (Jaccard, 1908), and the similarity matrix thus obtained was subjected to cluster analysis using the UPGMA (unweighted pair-group method with arithmetic average) algorithm. Similarity coefficients were also subjected to Principal Coordinate (PCO) analysis. Data analyses were performed using NTSYS-PC version 1.9 .

\section{RESULTS AND DISCUSSION}

Progress in crop breeding requires the exploitation of genetic variation among races and gene pools. Molecular

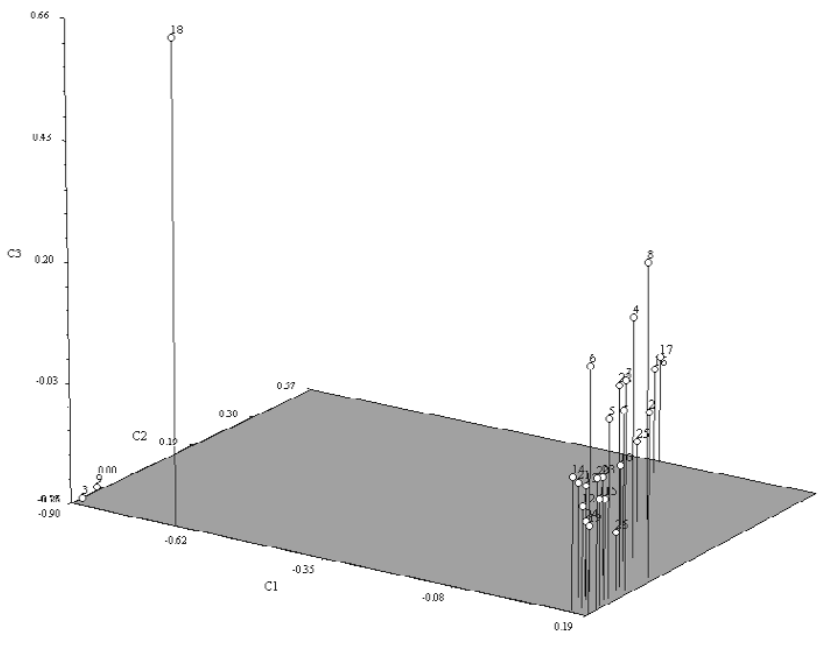

Principal Co-ordinate Analysis

Fig 3. Patterns of relationships among 26 common bean varieties revealed by principal coordinate analysis based on RAPD data. Numbers 1-26 in figure represents different varieties as shown in Table 1 .

markers are potentially useful in establishing genetic relationship among the wild species of common bean (Sharma 2006). Genetic diversity among twenty six varieties of common bean was investigated in the present study using 15 RAPD primers, which generated 124 bands/amplicons. The size of amplicons ranged from 200 $\mathrm{bp}$ to $2500 \mathrm{bp}$. The number of bands generated ranged from 4 to 17 with a mean of 8.26 bands per primer (Table 2). Out of 124 bands generated, 119 (95.96\%) were polymorphic and $5(4.03 \%)$ were monomorphic. Primer OPA-18 showed maximum number of polymorphic bands (17 bands). The percentage of polymorphic bands ranged from 83 to $100 \%$ with an average of $95.46 \%$. Out of total 15 primers, 10 displayed $100 \%$ polymorphism (Table 2). RAPD profiles obtained from primer OPA-15 and OPB-4 are shown in Fig. 1

Cluster analysis revealed that 26 varieties were grouped in two major clusters (Fig. 2). The clusters I and II contains 23 and three accessions, respectively. The genetic similarity coefficient (GS) values based on RAPDs for all the possible 325 pairs of genotypes ranged from 0.191 (between IC296363) and IC295928, Ooty FB2) to 0.923 (between IC118935, Malviya rajma (HUR-137) and IC118984) with a mean of 0.646 .

The results of principal coordinate analysis are shown in Fig. 3. The variation accounted in the first, second and third components accounted for $26.25 \%, 11.41 \%$ and $8.46 \%$ of total variation, respectively while the 
total variation was $46.12 \%$. The results of $\mathrm{PCO}$ corresponded well with cluster analysis obtained through UPGMA. The present results support the earlier views that RAPD analysis is a desirable technique for detection of genetic diversity in Indian common beans. Results of cluster analysis and PCO clearly showed the RAPD primers used in the present study can easily demarcates the accessions. The overall results indicated that a considerable diversity exists in a set of accessions analysed in the present investigation. This information can be used for selection of desirable parents for improvement of common beans.

\section{ACKNOWLEDGEMENTS}

Authors greatly acknowledged the laboratory, technical support and encouragement of Dr. B.S. Dhillon, ExDirector NBPGR, and New Delhi and Dr. Bhoopal Singh, Principal A. S. College Lakhaoti, Bulandshar (UP), for their constant and regular academic support.

\section{REFERENCES}

Anonymous (2003). FAO Production Year Book 56: 109-110. Beebe S, Skroch PW, Tohme J, Duque MC, Pedraza F and Nienhuis J (2000). Structure of genetic diversity among common bean landraces of Middle American originbased on correspondence analysis of RAPD. Crop Sci. 40: 264-273.

Gepts P and Bliss FA (1988). Dissemination pathways of common bean (Phaseolus vulgaris, Fabaceae) deduced from phaseolin electrophoretic variability. II. Europe and Africa. Econ. Bot. 42: 86-104.

Jaccard P (1908) Nouvelles recherches sur la distribution florale. Bull. which would be very useful to check the confirmity of Soc. Vaud. Sci. Nat. 44: 223-270.

Metais I, Hamon B, Jalouzot R and Peltier D (2002). Structure and level of genetic diversity in various bean types with microsatellite markers isolated from a genomic enriched library. Theor. Appl. Genet. 104: 1346-1352.

Saghai-Maroof MA, Soliman KM, Jorgensen RA and Allard RW (1984). Ribosomal DNA spacer length polymorphism in barley: Mendelian inheritance, chromosomal location, and population dynamics. Proc. Natl. Acad. Sci. U.S.A. 83: 1757-61.

Sharma TR, Rana JC, Sharma R, Rathore R and Sharma PN (2006). Genetic diversity analysis of exotic and Indian accessions of common bean (Phaseolus vulgaris L.) using RAPD markers. Indian J.Genet, 66(4): 275-278.

Zeven AC (1997). The introduction of the common bean (Phaseolus vulgaris L.) into Western Europe and the phenotypic variation of dry beans collected in The Netherlands in 1946. Euphytica 94: 319-328.

Zeven AC, Waninge J Hintum, Van T, Singh SP and van Hintum T (1999). Phenotypic variation in a core collection in common bean (Phaseolus vulgaris L.) in the Netherlands. Euphytica 109: 93-106. 